\title{
The influence of solid-phase organic carbon on the sorption of hydrophobic organic pollutants in landfill barriers, UK
}

\author{
Pin-Ru Huang ${ }^{1,2}$ (D) Anne Stringfellow ${ }^{3} \cdot$ Dave Smallman $^{3} \cdot$ John Marshall $^{2}$
}

Received: 25 September 2019 / Accepted: 5 April 2021 / Published online: 25 May 2021

(c) The Author(s) 2021

\begin{abstract}
The Oxford Clay from Bletchley, the Kimmeridge Clay from Kimmeridge Bay, Dorset, and Tertiary mud (Wittering Formation) from Whitecliff, Isle of Wight, United Kingdom were used as sorbent samples because of their distinctive organic material characteristics (Amorphous organic matter rich and/or phytoclast rich). Organic material was isolated for identification and analysis using a non-acid extraction method (heavy liquid) extraction and traditional methods involving HF digestion. These organic materials were then used to determine influences of extraction on hydrophobic organic contaminants, (toluene and naphthalene) sorption. Organic petrology classification was applied to identify the various types of isolated organic material. Amorphous organic matter from the Kimmeridge Clay displayed a higher sorption capacity (Sorption-desorption distribution coefficient $\left(K_{\mathrm{d}}\right), K_{\mathrm{d}}=6,481,59,670$; for toluene and naphthalene, respectively) compared to literature values. Amorphous organic matter-rich sorbent extracts demonstrated a higher absorption capacity than the phytoclast-rich sorbents (e.g., Wittering Formation, $K_{\mathrm{d}}=219,10,134$; for toluene and naphthalene, respectively). Implications of results in landfill design/risk assessment and modelling are discussed.
\end{abstract}

Keywords HOCs $\cdot \mathrm{SOM} \cdot$ Sorption $\cdot$ Risk assessment

\section{Introduction}

Modern landfills are designed with engineered barriers to prevent pollution of surface and groundwater. Low permeability barriers such as engineered clay liners may be used to limit transport of leachate or attenuate the concentration of pollutants by processes such as sorption (Fishman et al. 2012; Simoes et al. 2011). The potential for attenuation of leachate contaminants by landfill liners may be taken into account in regulatory risk assessment. Sorption may be estimated from easily measurable parameters such as $f_{\text {oc }}$ (the fraction of organic matter in the sorbent) and contaminant sorption coefficient values, (e.g., $K_{\mathrm{OC}}$ is the sorption

Pin-Ru Huang

pinruh@earth.sinica.edu.tw

1 Institute of Earth Sciences, Academia Sinica, PO Box 1-55, Nangang, Taipei 11529, Taiwan

2 School of Ocean and Earth Science, National Oceanography Centre, University of Southampton, European Way, Southampton SO14 3ZH, UK

3 School of Civil Engineering and the Environment, University of Southampton, Southampton SO16 7QF, UK coefficient normalized to the sorbent $f_{\text {oc }}$ ), which are commonly available in the literature (Delle Site 2001). However, greater than expected sorption capacity combined with apparently non-linear sorption isotherms have been reported in the literature and is considered to be due to the heterogeneous nature of the organic matter (Chi 2014; Chiou et al. 2000; Cornelissen et al. 2005; Huang et al. 2003; Weber et al. 2001). Simoes et al. (2011) found that hydrophobic organic contaminants (HOCs) present in landfill leachate (such as naphthalene, toluene and tetrachloromethane) sorbed to clay materials used as barriers in landfills. In their study, sorption of HOCs to Oxford Clay (OxC) was much stronger than predicted from contaminant hydrophobicity and this was attributed to the organic matter characteristics of the clay barrier material.

HOCs will sorb to different soil or sedimentary components including solid phase minerals, plant debris and organic matter, and majorly to the latest (Cornelissen et al. 2005; Trellu et al. 2016). The aromaticity and polarity of biochemical molecules are controlling factors and chemical elements such as organic carbon, oxygen, and hydrogen are important (Cornelissen et al. 2005; Delle Site 2001). The composition and the structure of the soil OM (SOM) is influenced by its source, type, age and 
alteration history (Cornelissen et al. 2005; Huang et al. 2003). These properties will influence the sorption affinity for nonionic organic compounds and the residence time of organic carbon in sediments (Han et al. 2016; Kennedy et al. 2002; Perez et al. 2011).

The impact of sediment diagenetic changes after burial on the attachment of HOCs to SOM has been investigated through experiments simulating diagenesis through the use of high temperature and pressure (Guo et al. 2013). Treated samples were found to have an increased surface area and number of pores (Guo et al. 2013; Han et al. 2018). This was believed to provide substantial additional voids for HOCs. Additionally, after simulated diagenesis, treated samples show greater sorption nonlinearity and increased sorption capacity (Han et al. 2018).

The examination of OM can be achieved by chemical methods or changes in morphology. Chemical methods are capable of measuring elemental composition, whereas organic petrological techniques can give structural OM compositional information. Organic petrology can be used to examine components such as coal and charcoal, from the remains of microorganisms, plants and animals, which can predetermine the heterogeneous character of the resultant OM (Lichtfouse et al. 2005; Ligouis et al. 2005) and can also provide a visual interpretation of the interface between HOCs and OM. Karapanagioti and Sabatini (2000) and Huang et al. (2006), suggested estimations for sorption capacity by organic petrology analysis quantification.

As stated in Simoes et al. (2011), the selection of appropriate sorption parameters for use in landfill risk assessment is difficult because of the wide range of values available in the literature and because the types of OM found in clayrich sediments used in landfill barriers may be significantly different to soils and sediments previously studied. Simoes et al. (2011) demonstrated through petrological examination that $\mathrm{OxC}$ had a high concentration of amorphous organic matter and excess sorption was attributed to the presence of this type of $\mathrm{OM}$ in the clay barrier material. This research is extended here by considering sorption of HOCs to other types of sediments which have different OM compositions and have undergone varying degrees of diagenesis. The overall aim of the study was to determine the influence of different types of sedimentary OM on the sorption of HOCs through chemical and petrological methods and determine whether petrology can be used to predict sorption. The study investigated the sorption of two HOCs (toluene, naphthalene) commonly found in landfill leachate onto the following: [1] three different formations and [2] the OM extracted from these sediments/clays.

\section{Materials and methods}

\section{Materials}

\section{Barrier materials (sorbent)}

Three barrier materials were chosen to present different and distinct types of OM, this because of their high variability in terms of character and maturation due to the sedimentary history (i.e., Tertiary or Jurassic). These include Kimmeridge Clay (KC) from Kimmeridge Bay, Dorset, UK which is a bituminous shale (SY91916 77760), the Wittering Formation (WF) is from sandy clay with lignitic logs scattered among it (SZ63899 86027), and the Oxford Clay $(\mathrm{OxC})$ from Bletchley, UK is from mudstone with well-preserved OM and fossils. Figure 1 in the supplementary material shows the geographical distribution of the three sediments/clays in the UK. Both $\mathrm{KC}$ and $\mathrm{OxC}$ were deposited during the Jurassic, and it could be expected that these would have similar geological history. Conversely, the WF provided sandy material and abundant phytoclasts (plant debris) from a younger geological time, the Tertiary. $\mathrm{KC}$ and $\mathrm{OxC}$ sediments have been used as clay barrier materials in landfills; the WF was used in the study to provide a sample with significantly different $\mathrm{OM}$.

The KC Formation was deposited in a series of basin that are distributed across the North Atlantic area. Though the KC is the source rock for most North Sea oil fields, the burial depth is shallower in Dorset, consequently there was insufficient pressure and heat for the type II kerogen to mature (Fishman et al. 2012). The average TOC is 8 $\mathrm{wt} \%$, but varies between 3 and $26 \mathrm{wt} \%$ (Morgans-Bell et al. 2001). The Blackstone Bed among four lithological units has an abundant TOC of over $35 \mathrm{wt} \%$, with typical contents between 8 and $15 \mathrm{wt} \%$; this material was selected for the study because the kerogen can be extracted more efficiently. The majority of the KC OM is amorphous organic matter of marine origin ( $75 \%$ and $95 \%$, in) The OM of the $\mathrm{KC}$ has been classified as Type II kerogen.

The $\mathrm{OxC} \mathrm{OM}$ is also immature in terms of petroleum generation potential (Delle Site 2001). Petrographic analysis (Delle Site 2001) divides the Peterborough Member into an organic-rich group (TOC $12.2 \sim 14.2 \%$ ) and the medium content TOC Peterborough Member (TOC $5.2 \sim 5.6 \%$ ) that was used in this study. The reason for using a medium-TOC rather than the organic-rich is that it is more typical of the TOC in $\mathrm{OxC}$. The two groups exhibit different palynofacies characteristics: the higher organic carbon content group has a greater AOM component of type II kerogen than the other, and the remaining components are plant fragments, pollen, spores, microplankton and lignitic debris. 
The Eocene sediments at Whitecliff Bay is a reference section for the global chronostratigraphical and eustatic schemes. The estuarine laminated sandy clays in the Wittering Formation include rooted coals (Huggett et al. 2005).

All three sampling sites were outcrop and composed of loose components compared to the underlying rock. After documenting the location of the site [photographically and with global positioning system (GPS) tracking] and removal of allogenic material, samples were extracted from the exposed solid rock using shovels, chisels and geological hammers and placed in ziploc bags and plastic box containers for storage. At least two kilograms of each sediment was taken for analysis and organic matter extraction.

\section{Leachate}

To simulate landfill conditions, a synthetic leachate is used in the sorption experiments. This was used rather than real leachate to maintain a stable and repeatable composition throughout the sorption testing (Cornelissen et al. 2005). The synthetic leachate was designed to represent a typical UK municipal solid waste (MSW) leachate (Table 1 in supplementary material) (Environment Agency 2009; Simoes et al. 2011).

As a surrogate, the level of aromaticity, molecular weight, carbon/nitrogen ratio and reactivity of artificial materials (tannic acid) may not be representative of either leachate humic or fulvic acid (Simoes et al. 2011). However, in this research it was considered to be the best surrogate for DOC (dissolved organic carbon) in leachate. The synthetic leachate was found to react with oxygen such that darkening and precipitation of DOC were observed. As such the solution was stored in an anaerobic cabinet in an atmosphere of $90 \% \mathrm{~N}_{2}, 5 \% \mathrm{CO}_{2}$ and $5 \% \mathrm{H}_{2}$ (Wolflabs Model A Vinyl cabinet) to prevent precipitation of tannic acid. The batch sorption tests were also prepared in the anaerobic glovebox.

\section{Analytical compounds}

Naphthalene and toluene were chosen as examples of HOC pollutants to be used in this study because they are often found in landfill leachate. They have different hydrophobicities with the $\log \mathrm{K}_{\mathrm{OW}}$ of naphthalene being 3.17 and that of toluene 2.54 (Mackay and Gschwend 2000). The physicochemical properties of the hazardous substances are shown in supplementary material Table 2 . Analytical-grade naphthalene (solid) from Sigma Aldrich Chemical Co. (Ebukanson and Kinghorn) and analytic grade toluene from Fisher Scientific (Ebukanson and Kinghorn) were used as HOCs.

\section{Petrology analysis}

Sediment samples were dried and milled and the TOC determined on a Carlo-Erba EA1108 elemental analyser as total carbon [TC] and then on decarbonated sediments/clays using the $\mathrm{HCl}$ fumigation method (Harris et al. 2001; Yamamoto et al. 2001). The elemental analysis (N, C, O, S, H) of the sediments and isolated OM was measured by OEA Ltd (Organic Elemental Analysis Laboratories Limited). The elemental analysis determined total carbon, hydrogen, nitrogen and sulphur simultaneously. The detection limits were $0.01 \%$ for $\mathrm{C}, \mathrm{N}, \mathrm{O}$ and $\mathrm{H}$, and $0.05 \%$ for sulphur.

The samples of the $\mathrm{OxC}, \mathrm{KC}$ and $\mathrm{WF}$ were air-dried, crushed and then sieved to $\mathrm{a} \leq 3 \mu \mathrm{m}$ particle size and stored in air-tight containers. Mineral contents were determined by X-ray diffraction (XRD) using a Philips PW 3040/60 X-ray Diffractometer and linked X'Pert software. Precision values and detection limits for mineral analysis of crystalline materials are generally of the order of $\pm 0.5-2 \%$, and for total clay precision values of $\pm 15 \%$.

Microscopic methods were used for determination of kerogen type and maturity of that portion of kerogen which was microscopically recognizable, or structured. The HF digestion residues and heavy liquid floating $\mathrm{OM}$ were mounted in Elvacite 2044 ${ }^{\mathrm{TM}}$ to make transmitted light slides for point counting. This gave a percentage of the different OM types. These types were identified by using a transmitted light microscope based on microfossil morphology.

\section{Methods of extraction of SOM from clay barrier materials}

Dried material was treated by two different extraction methods: [1] HF acid digestion (Yule et al. 2000), and [2] heavy liquid separation (Riding and Kyffin-Hughes 2009).

\section{HF digestion}

The sediment/clay was weighed and placed into plastic beakers for acid digestion in a fume cupboard. First, $30 \% \mathrm{HCl}$ was added to remove the carbonate. The sample was then washed to neutral pH. $60 \% \mathrm{HF}$ was then added to dissolve the majority of the silicates, then decanted and the residue washed to neutral $\mathrm{pH}$. The sample was then treated with hot concentrated $\mathrm{HCl}$ to dissolve fluorides which had formed during the HF digestion. The solution was then neutralized by dilution with water. Slides of the residue were again mounted in Elvacite 2044 for point counting using a transmitted light microscope.

2. Heavy liquid separation

This was carried out on samples which were initially dispersed, using Calgon $\left(\mathrm{NaPO}_{3}\right)_{6}$, neutral, nonoxide) to remove the silicate clay (Riding and Kyffin- 
Hughes 2009). The samples were then placed in an ultra-sonic tank, disaggregated and sieved at $15 \mu \mathrm{m}$ (Riding and Kyffin-Hughes 2009). This deflocculation and sieving method was repeated until no cloudy suspension remained.

In this study, instead of using heavy liquid zinc bromide $\left(\mathrm{ZnBr}_{2}\right)$, LST Fastfloat (Pangea UK) was used. Fastfloat (hydrated sodium heteropolytungstate $\left(\mathrm{Li}_{\mathrm{m}} \mathrm{Na}_{\mathrm{m}}\left(\mathrm{W}_{12} \mathrm{O}_{40}\right)\right.$, $80 \mathrm{wt} \%$ dissolved in water) has a low-toxicity and is a lowviscosity heavy liquid and has the advantage of being reusable. Taking into account the density of the OM [i.e., vitrinite $\left(1.25 \sim 1.4 \mathrm{~g} / \mathrm{cm}^{3}\right)$ and semifusinite $\left(1.4 \sim 1.7 \mathrm{~g} / \mathrm{cm}^{3}\right)$, kerogen type II $\left(1.15 \sim 1.25 \mathrm{~g} / \mathrm{cm}^{3}\right)$ ] (Okiongbo et al. 2005; Pilawa et al. 2002; Tyson 2012), a $2.0-\mathrm{g} / \mathrm{cm}^{3}$ density Fastfloat was prepared because the majority of the silicates in the rocks was clay, and the density demarcation between OM and minerals was $2.0 \mathrm{~g} / \mathrm{cm}^{3}$. After putting the dried sample in the Fastfloat, a sonication bath was used to ensure thorough mixing. The sample was then centrifuged for $3 \mathrm{~min}$ at a speed of $1400 \mathrm{rpm}$. The floating particles were then decanted to separate them from the heavier fraction. Deionised water was added to reduce the solution density until the suspension started to sink. Further centrifugation was then used until the Fastfloat had been removed. The OM was collected by filtering with a glass microfibre filter paper (Whatman, pore size $0.1 \mu \mathrm{m})$.

\section{Sorption tests}

The batch sorption method used in this study followed the procedure of Simoes et al. (2011). Amounts of solid samples (either extracted OM or sediments/clays, Table 3 and Table 4) were prepared for interaction with leachate. After the HOC contaminants were added, the glass bottles (122 ml internal volume, Sigma Aldrich, UK) were sealed immediately with aluminium caps and Teflon ${ }^{\circledR}$-coated septa. These have been reported to cause loss of solute (Cornelissen et al. 2005) but no significant losses were found using a 7 -day contact time. The sorbent and sorbate were mixed by horizontal rotary agitation, at $20 \pm 2{ }^{\circ} \mathrm{C}$ in a constant temperature room. After 7 days of rolling, solids were separated from the aqueous solutions by centrifugation at $1500 \mathrm{rpm}$ for $40 \mathrm{~min}$ (naphthalene) or $1 \mathrm{~h}$ (toluene). Sodium chloride $(3 \mathrm{~g})$ and sample $(9.9 \mathrm{ml})$ were added to headspace vials (Sigma-Aldrich, UK) together with internal standard dichlorobenzene(1,4-DCB) and 1,4difluorobenzene(1,4DFB) $(100 \mu \mathrm{l})$, followed by analysis using Gas chromatography-mass spectrometry (GC-MS).

Initial tests were carried out to determine the solid/liquid $(\mathrm{S} / \mathrm{L})$ ratio required to allow measurable changes in aqueous contaminant concentration during sorption (20-80\%). The resultant $\mathrm{S} / \mathrm{L}$ ratios used for the clay barrier materials and extracts are shown in Tables 3, 4. Subsequent tests allowed the generation of sorption isotherms. The concentration ranges used in this study were limited to match those found in landfill leachate (Environment Agency 2001, 2003): toluene from 60 to $400 \mu \mathrm{g} / \mathrm{l}$, naphthalene from 0.25 to $50 \mu \mathrm{g} / \mathrm{l}$.

\section{Results and discussion}

Abbreviations to those samples used in this study are listed below as follows

$\mathrm{OM}_{\mathrm{HF}}$ : Organic matter extracted by $\mathrm{HF}$ digestion from $\mathrm{KC}, \mathrm{OxC}$ and $\mathrm{WF}$

$\mathrm{KC}_{\mathrm{HF}}: \mathrm{HF}$ digestion residues from the $\mathrm{KC}$

$\mathrm{OxC}_{\mathrm{HF}}$ : $\mathrm{HF}$ digestion residues from the $\mathrm{OxC}$

$\mathrm{WF}_{\mathrm{HF}}$ : $\mathrm{HF}$ digestion residues from the WF

$\mathrm{OM}_{\mathrm{HL}}$ : Organic matter extracted by heavy liquid from $\mathrm{KC}, \mathrm{OxC}$ and $\mathrm{WF}$

$\mathrm{KC}_{\mathrm{HL}}$ : OM separated from the $\mathrm{KC}$ by heavy liquid

$\mathrm{OxC}_{\mathrm{HL}}$ : $\mathrm{OM}$ separated from the $\mathrm{OxC}$ by heavy liquid

$\mathrm{WF}_{\mathrm{HL}}$ : OM separated from the Wittering Formation by heavy liquid

\section{Characterization of sorbent}

\section{Mineral quantified analysis of the sediments/ clays and organic matter}

Table 1 provides the mineralogy compositions, sediments/ clay and of their heavy- liquid- extracted OM. The $\mathrm{KC}$ has median clay mineral proportion $(51.4 \%)$ of the three sediments/clays; the non-clay minerals were mainly quartz with minor calcite and accessory mineral pyrite. The OxC had the largest clay mineral proportion $(58.2 \%)$; non-clay minerals included quartz, feldspars, calcite, gypsum, and accessory mineral pyrite. The WF, which is a siltstone with dispersed lignite, contained the highest percentage of sand-sized quartz (40.6\%) and clay minerals (30.2\%) with feldspars, minor calcite, and accessory mineral pyrite. The clay components of the free sediments were major illite with minor kaolinite. The missing part of the total mineral sum (100\%) is attributed to residual $\mathrm{OM}$ and/or water.

The advantage of SOM gathered from demineralised sediments/clays using hydrofluoric acid (HF) is the higher purity of SOM which enables the investigation to focus on the SOM contribution to sorption of HOCs. However, the heavyliquid-enriched SOM is less subject to chemical alteration (Riding and Kyffin-Hughes 2009). Through XRD analysis, the heavy-liquid-separated organic matter was found detectable minerals remains. This finding indicates not only organic matter involved in the sorption process but also remaining minerals (Table 1). Those remaining minerals could involve and/or interfere the sorption process of HOCs. This could 
Table 1 Mineral composition and moisture contents of the Kimmeridge Clay [KC], Wittering Fm [WF] and Oxford Clay $[\mathrm{OxC}]$ and mineral composition of OM separated by heavy liquid $\mathrm{HL}$

\begin{tabular}{lllllll}
\hline Mineral (wt\%) & $\mathrm{KC}$ & $\mathrm{OxC}$ & $\mathrm{WF}$ & $\mathrm{KC}_{\mathrm{HL}}$ & $\mathrm{OxC}_{\mathrm{HL}}$ & $\mathrm{WF}_{\mathrm{HL}}$ \\
\hline Illite & 36.3 & 42.4 & 24.7 & 46.9 & $10-25$ & - \\
Kaolinite & 15.1 & 13.8 & 5.5 & 17.5 & $2-3$ & - \\
Smectite & - & 1.5 & - & - & - & - \\
Chlorite & - & 0.5 & - & - & - & - \\
Feldspars & - & 2.9 & 5.3 & - & - & - \\
Quartz & 14.8 & 16.1 & 40.6 & 10.1 & 50 & 7.9 \\
Calcite & 7.0 & 9.2 & 0.2 & 0.1 & - & 1.1 \\
Gypsum & - & 5.1 & - & - & - & - \\
Pyrite & 1.3 & 0.7 & 1.7 & 1.5 & $2-3$ & 5.2 \\
Total & 74.5 & 92.2 & 77.9 & 76.1 & $64-81$ & 14.2 \\
TOC $(\%)$ & $21.4 \pm 0.2$ & $5.5 \pm 0.2$ & $2.8 \pm 0.1$ & & & \\
Moisture content (\%) & $4.8 \pm 1.9$ & $19.5 \pm 0.1$ & $20.8 \pm 0.0$ & & & \\
\hline
\end{tabular}

The detection limitation of X-ray Diffraction (XRD) is $0.5 \%$. - : Not detected, $\mathrm{OxC}_{\mathrm{HL}}$ : qualitative analysis because of limited sample availability result in variation in sorption characteristics between the two extraction methods: HF digestion and LST separation. However, the efficacy of heavy liquid separation OM for chemical elements analysis is open to question, while this LST separation could be efficacy for kerogen morphological observation (Riding and Kyffin-Hughes 2009).

\section{Geochemical analysis of sediments/clays and organic matter}

The TOC contents of the sediments/clays decreased in the following order: $\mathrm{KC}>\mathrm{OxC}>\mathrm{WF}$ (Table 1). Polarity of the sediments (Table 2) increased in the following order: $\mathrm{KC}<\mathrm{OxC}<\mathrm{WF}$, the $\mathrm{H} / \mathrm{C}$ and $\mathrm{O} / \mathrm{C}$ atomic ratios /clays followed the same trend (Table 2). The reason we study the atomic ratio is that increasing $\mathrm{H} / \mathrm{C}$ and $\mathrm{O} / \mathrm{C}$ atomic ratios have been found to be indicative of enhanced sorption capacity (Cornelissen et al. 2005; Jin and Zimmerman 2010; Weber et al. 2001; Zhang and He 2010) and that increasing $\mathrm{O} / \mathrm{C}$ ratio has also been found to be correlated to increasing isotherm linearity (Cornelissen et al. 2005; Weber et al. 2001).

The polarity index (PI) of the sediments was higher than the corresponding extracted OM. For example, the polarity of $\mathrm{KC}$ decreased in the following order: $\mathrm{KC}$ $(0.4)>\mathrm{KC}_{\mathrm{HL}}(0.2)>\mathrm{KC}_{\mathrm{HF}}(0.1)$ (Table 2). Similarly, the $\mathrm{H} / \mathrm{C}$ and $\mathrm{O} / \mathrm{C}$ atomic ratios of the sediments were generally higher than their corresponding extracted OM. In this study, the $\mathrm{O} / \mathrm{C}$ atomic ratio of $\mathrm{OM}_{\mathrm{HL}}$ and $\mathrm{OM}_{\mathrm{HF}}$ decreased in the order $\mathrm{WF}>\mathrm{OxC}>\mathrm{KC}$. The $\mathrm{H} / \mathrm{C}$ atomic ratios behaved differently; the acid-extracted $\mathrm{H} / \mathrm{C}$ atomic ratios decreases as $\mathrm{OxC}_{\mathrm{HF}}=\mathrm{KC}_{\mathrm{HF}}>\mathrm{WF}_{\mathrm{HF}}$, whereas the ratios

Table 2 Summary of the elemental compositions polarity index (PI), H/C and O/C ratios in sediments/clays for the Kimmeridge Clay [KC], Wittering Fm $[\mathrm{WF}]$ and Oxford Clay $[\mathrm{OxC}]$ and their corresponding heavy liquid (HL) and hydrofluoric acid (HF) extracted OM

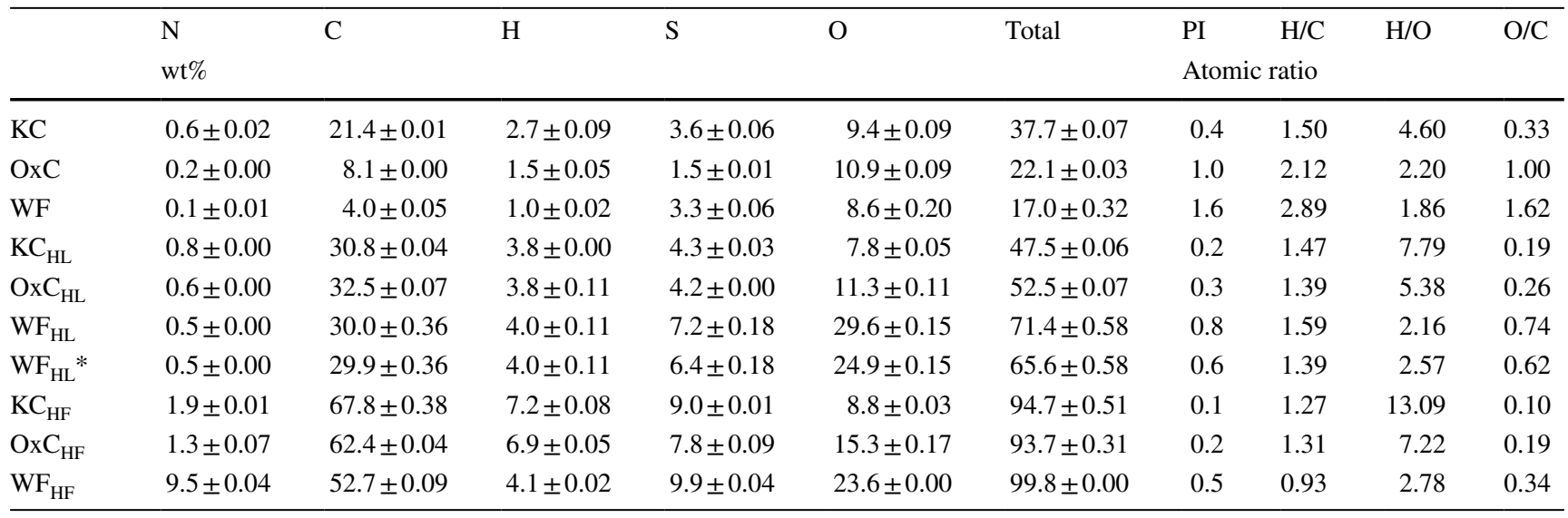

Polarity index $(\mathrm{PI})[(\mathrm{O}+\mathrm{N}) / \mathrm{C}]$ of $\mathrm{OM}$ was calculated from the atomic ratio of $(\mathrm{O}+\mathrm{N})$ and $\mathrm{C}($ Cornelissen et al. 2005). H/C and O/C were calculated from the corresponding atomic ratios. *Data with minerals content removed 
of $\mathrm{OM}_{\mathrm{HL}}$ decreased as $\mathrm{KC}_{\mathrm{HL}}>\mathrm{WF}_{\mathrm{HL}}=\mathrm{OxC}_{\mathrm{HL}}$ (Table 2). Among $\mathrm{OM}$ extracted by HF acid digestion, $\mathrm{AOM}$ dominated samples $\left(\mathrm{KC}_{\mathrm{HF}}\right)$ had the lowest $\mathrm{O} / \mathrm{C}$ atomic ratio and the phytoclast dominated samples $\left(\mathrm{WF}_{\mathrm{HF}}\right)$ had the lowest $\mathrm{H} / \mathrm{C}$ ratio.

The reduced $\mathrm{H} / \mathrm{C}$ and $\mathrm{O} / \mathrm{C}$ values of $\mathrm{OM}$ extracted by HF digestion compared to heavy- liquid- extracted OM were mainly due to the mineral component contribution to $\mathrm{H}$ and $\mathrm{O}$ in the $\mathrm{OM}_{\mathrm{HL}}$ samples. Although $\mathrm{OM}_{\mathrm{HL}}$ still has calcite which contributes $\mathrm{C}$, the amount is comparatively small compared to the $\mathrm{H}$ and $\mathrm{O}$ content in clay mineral and quartz. Hence, $\mathrm{H} / \mathrm{C}$ and $\mathrm{O} / \mathrm{C}$ values of $\mathrm{OM}_{\mathrm{HL}}$ were not suitable for the Van Krevelen diagram.

\section{Characterization of the organic matter}

\section{Geochemical characterization and classification of OM}

The average $\mathrm{H} / \mathrm{C}$ and $\mathrm{O} / \mathrm{C}$ atomic ratios of $\mathrm{OM}_{\mathrm{HF}}$ are plotted on the Van Krevelen diagram in Fig. 1. The total weight percentage of the HF digestion-extracted OM ranged from 93.4 to $99.8 \%$. In contrast, the total weight percentages of the heavy- liquid- extracted OM were found to range from 47.5 to $71.4 \%$. As these samples may contain other minerals over $15 \%$ by weight, they are not plotted on the Van Krevelen plot. Inspection of the plot (Fig. 1) reveals that kerogen samples from the KC (Fishman et al. 2012; Morgans-Bell et al. 2001) and the OxC (Delle Site 2001) are immature Type II kerogens, consistent with previous studies of these samples, and that the woody kerogen from WF are Type III kerogen (Huggett et al. 2005).

\section{Microscopic observation on quantification, characterization and classification of extracted organic matter}

In the petrological analyses of samples, 100 kerogen particles were counted at $\times 400$ on a transmitted light slide using. Optical observation showed AOM with a sharp edge in the $\mathrm{KC}_{\mathrm{HF}}$ which is predominantly palynofacies (79\% and $89 \%)$ and a minor maceral component of phytoclasts $(6 \%$ and 7\%) (Figs. 2a, 3). The phytoclast component in the $\mathrm{KC}_{\mathrm{HF}}$ was measured by the reflectivity show mainly lowrank $(<0.5 \%)$ vitrinite with very little higher rank fusinite $(>1.6 \%)$ (Fig. 4).

The $\mathrm{WF}_{\mathrm{HF}}$ consists mainly of phytoclasts $(61 \%$, Figs. $2 \mathrm{c}$, 3 ), with entirely low-rank vitrinite (Fig. 4). The heavy- liquid- extracted OM from KC (Fig. 2d), OxC (Fig. 2e) and WF (Fig. 2f) observed under microscope was similar to the kerogen extracted by HF digestion. The preservation of OM is prominent in the HF- extracted OxC (Fig. 2b). Microscopic examination identified amorphous kerogen $(58 \%$ and $73 \%)$, marine microplankton (31\% and $8 \%$ ) (dinoflagellate cysts, acritarchs) and black opaque tissue from land plants (11\% and 9\%) (Figs. 2b, 3). Details of the OxC kerogen have been described in a previous work (Simoes et al. 2011).

\section{Sorption of organic contaminants}

Linear sorption isotherms for sediments/clays, heavy-liquidextracted OM, and HF-extracted OM are shown in Fig. 5. All sorption equilibrium data measured for the three sediments/
Fig. 1 Van Krevelen atomic diagram with superimposed elementary composition ratios $(\mathrm{H} / \mathrm{C}$ and $\mathrm{O} / \mathrm{C})$ of kerogen extracted $\mathrm{OM}$ by HF digestion from the Kimmeridge Clay $\left[\mathrm{KC}_{\mathrm{HF}}\right]$, the Oxford Clay $\left[\mathrm{OxC}_{\mathrm{HF}}\right]$ and the Wittering Fm $\left[\mathrm{WF}_{\mathrm{HF}}\right]$

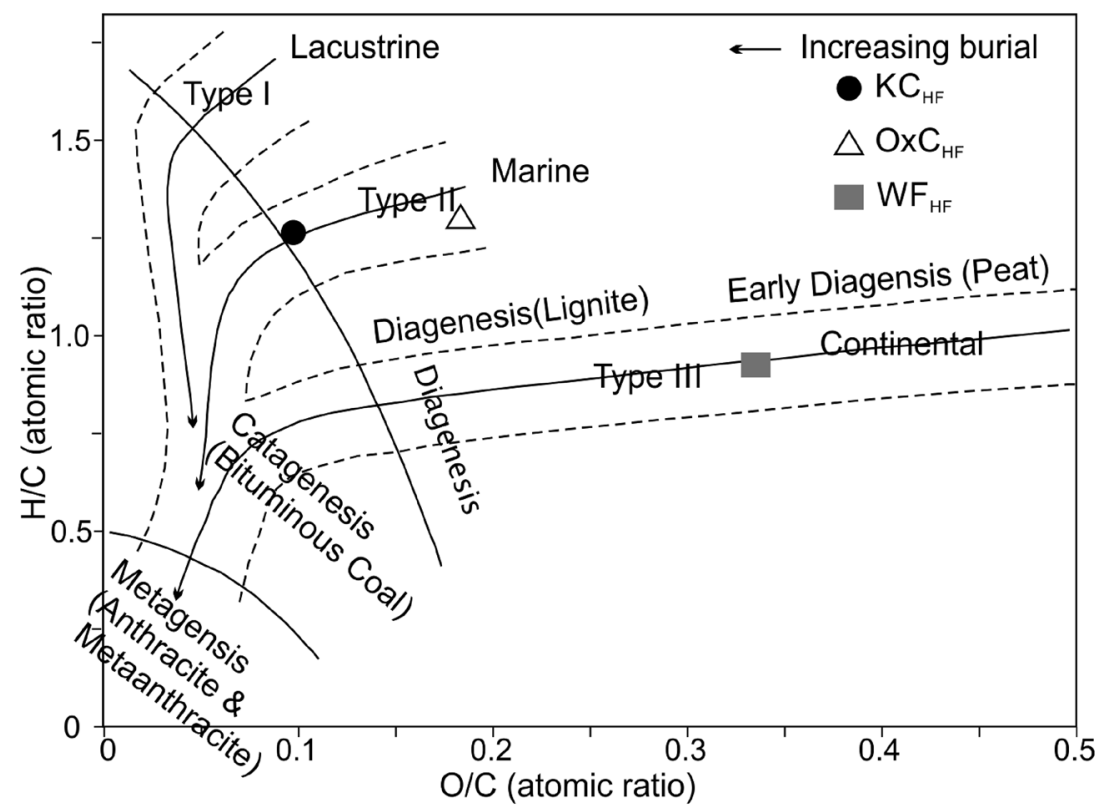




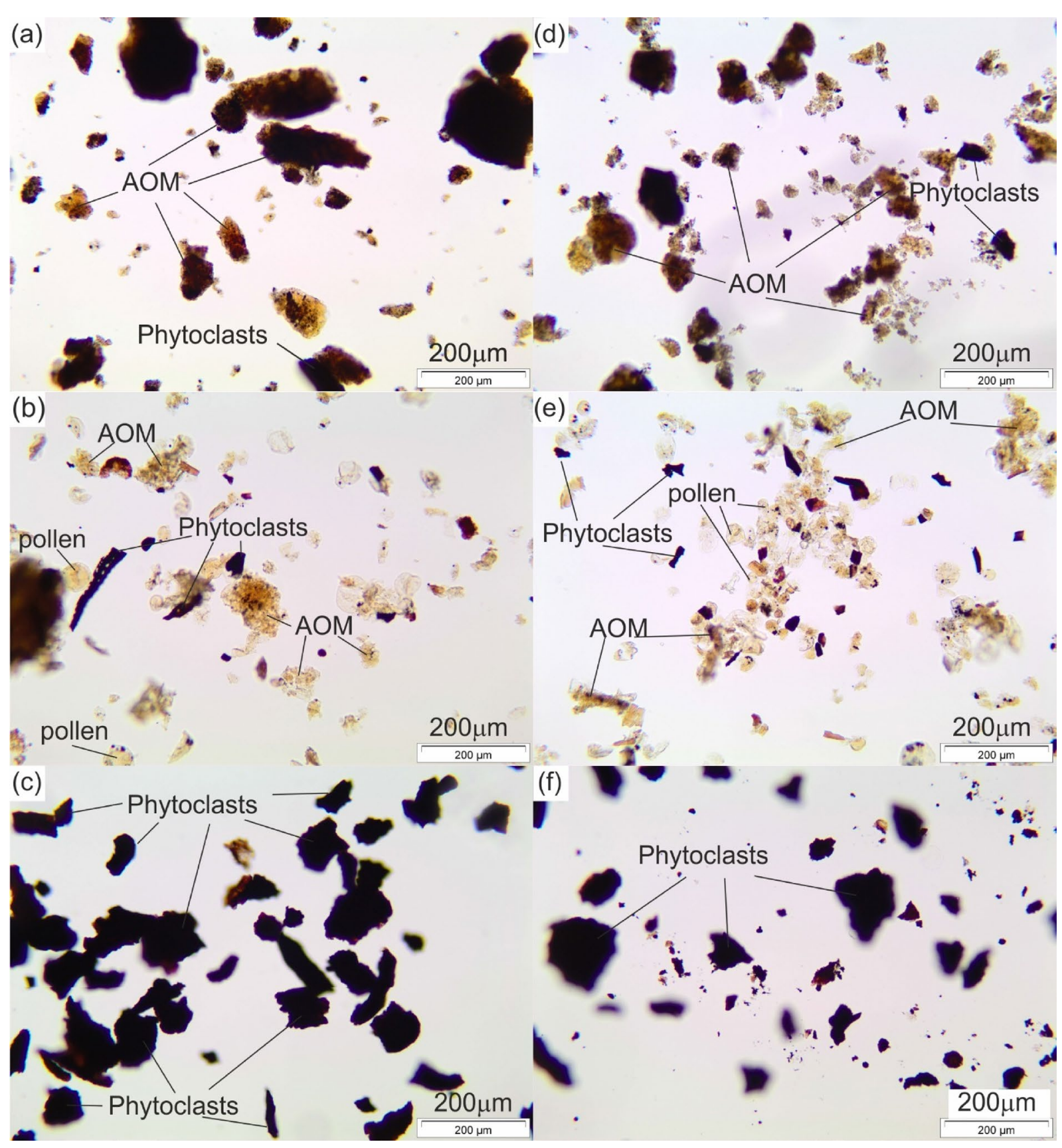

Fig. $2 \mathrm{OM}$ isolated from sediments/clays viewed under incident light microscopy. a $\mathrm{KC}_{\mathrm{HF}}, \mathbf{b} \mathrm{OxC}_{\mathrm{HF}}, \mathbf{c} \mathrm{WF}_{\mathrm{HF}}, \mathbf{d ~} \mathrm{KC}_{\mathrm{HL}}, \mathbf{e} \mathrm{OxC}_{\mathrm{HL}}, \mathbf{f} \mathrm{WF}_{\mathrm{HL}}$. *AOM (Amorphous OM)

clays and extracted OM were fitted to both the linear sorption isotherm model and the Freundlich sorption isotherm model (Tables 3, 4). Non-linearity has been shown to exist typically over three orders of magnitude or more at concentrations up to 10 or $20 \%$ of the compound's water solubility (Cornelissen et al. 2005). The concentration range in this study was narrow, less than three orders of magnitude and thus the Freundlich model linearity index was close to 1 in most cases.

The linear sorption coefficient $\left(K_{\mathrm{d}}, \mathrm{ml} / \mathrm{g}\right)$ for naphthalene $(388 \mathrm{ml} / \mathrm{g}-8073 \mathrm{ml} / \mathrm{g})$ was found to be greater than for toluene $(37 \mathrm{ml} / \mathrm{g}-887 \mathrm{ml} / \mathrm{g}$ ) (Tables 3, 4). The aqueous solubility of naphthalene $(142.1 \mathrm{mg} / \mathrm{l})$ is less than that for toluene $(573.1 \mathrm{mg} / \mathrm{l})$. Similar results were also found by Jin and Zimmerman (2010) and Headley et al. (2001). The $K_{\mathrm{d}}$ values of the HOCs on the corresponding 


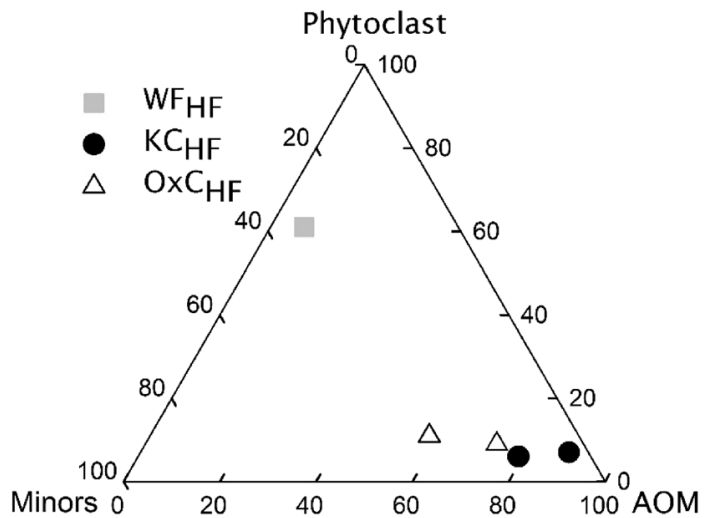

Fig. 3 Microfossil component ternary plot of the extracted OM (HF) from the Wittering, Kimmeridge Clay and Oxford Clay formations

extracted $\mathrm{OM}$ have the same decreasing order, i.e., $\mathrm{KC}>\mathrm{OxC}>\mathrm{WF}$ which corresponds to the TOC content.

\section{Sorption capacity of the barrier clay for toluene and naphthalene}

The linear sorption coefficients for the two HOCs and three sediments/clays were compared to literature values (supplementary material Table 3). Values for toluene $K_{\mathrm{d}}$ ranged from 0.1 to $153.6 \mathrm{ml} / \mathrm{g}$. In this study, the toluene $K_{\mathrm{d}}$ measured from the $\mathrm{OxC}(94 \mathrm{ml} / \mathrm{g})$ and the $\mathrm{WF}(37 \mathrm{ml} / \mathrm{g})$ were within this range, but $\mathrm{KC}$ was significantly higher at $887 \mathrm{ml} / \mathrm{g}$ (Supplementary material Table 3a). Similarly, the naphthalene sorption coefficient derived in this study for $\mathrm{KC}$ $(8073 \mathrm{ml} / \mathrm{g}$ ) was high but still within the range of literature values, from $0.2 \mathrm{ml} / \mathrm{g}$ to $8530 \mathrm{ml} / \mathrm{g}$. This extraordinarily high sorption capacity of KC could be due to the high TOC in comparison to the other sediments described in the literature and/or a function of the type of OM present.

Published $\log K_{\mathrm{OC}}$ values ( $K_{\mathrm{d}}$ normalised to the OM content) of toluene range from 1.52 to $3.8(\mathrm{ml} / \mathrm{g}$ ), (supplementary material Table $3 \mathrm{a}$ ), whereas the $\log K_{\mathrm{OC}}$ values measured in this study ranged from 2.62 to $3.98 \mathrm{ml} / \mathrm{g}$ (Table 4). Published $\log K_{\mathrm{OC}}$ values of naphthalene ranged from 1.28 to $4.64 \mathrm{ml} / \mathrm{g}$ (supplementary material Table $3 \mathrm{~b}$ ); here the $\log K_{\mathrm{OC}}$ values of naphthalene ranged from 3.91 to $4.94 \mathrm{ml} / \mathrm{g}$. In both cases $\mathrm{K}_{\mathrm{OC}}$ values obtained in this study were higher than the literature values indicating that the sorption capacity was influenced by intrinsic OM structural properties. The $\log K_{\mathrm{OC}}$ of naphthalene measured from $\mathrm{KC}_{\mathrm{HF}}$ is the highest among literature.

To facilitate direct comparisons of sorption affinities amongst the samples tested, $\log K_{\mathrm{OC}}$ values were plotted against TOC\% (Fig. 6). Sediments/clays and extracted $\mathrm{OM}$ had $K_{\mathrm{OC}}$ values for both toluene and naphthalene that decreased in the following order: $\mathrm{KC}>\mathrm{OxC}>\mathrm{WF}$. The apparent differences indicate different sorption capacity amongst the different types of OM and the sediments/clays. The microfossil component combination shown in Fig. 3 shows that the major component of $\mathrm{OM}$ in $\mathrm{KC}$ was $\mathrm{AOM}$ (79\%) whilst $\mathrm{OxC}$ had a content of $58 \%$. The toluene and naphthalene sorption was greater in $\mathrm{KC}_{\mathrm{HF}}$ where $\mathrm{AOM}$ dominated the $\mathrm{OM}$ assemblage and phytoclasts contributed only $6 \%$. Sorption was reduced in $\mathrm{WF}_{\mathrm{HF}}$ where phytoclasts dominated the OM assemblage (61\%) and AOM only contributed $7 \%$. From this, it can be concluded that where AOM is the dominant component of the OM, which is clearly evident in $\mathrm{KC}$ and $\mathrm{OxC}$, there is a much greater sorption capability than in phytoclast-dominated OM in WF.

The heavy-liquid-extracted OM produced comparatively similar $K_{\mathrm{OC}}$ values to the original sediments/clays (Fig. 6) in most cases. This suggests that this method did not alter the sorption capacity. However, the naphthalene $K_{\mathrm{OC}}$ value for Oxford Clay heavy-liquid-extracted $\mathrm{OM}$ was approximately three times less than the $K_{\mathrm{OC}}$ of the original clay: $\mathrm{OxC}_{\mathrm{HL}}$ $(12,213 \mathrm{ml} / \mathrm{g})$ compared to $\mathrm{OxC}(38,855 \mathrm{ml} / \mathrm{g})$. It is not clear why the heavy-liquid treatment affected naphthalene sorption in this way.

All the HF digestion-enriched OM showed greater $K_{\mathrm{OC}}$ values than the heavy-liquid-enriched OM (Fig. 6), except
Fig. 4 Histograms of phytoclast reflectivity from the extracted $\mathrm{OM}(\mathrm{HF})$ from the Wittering, Kimmeridge Clay and Oxford Clay formations (a)

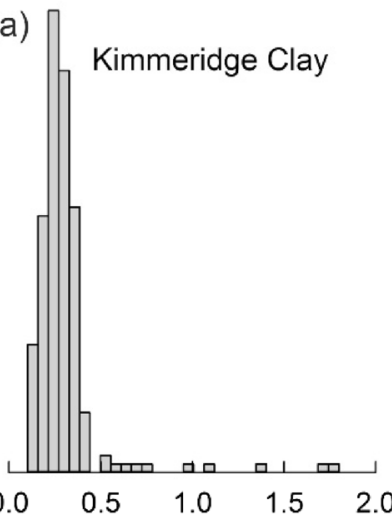

(b)

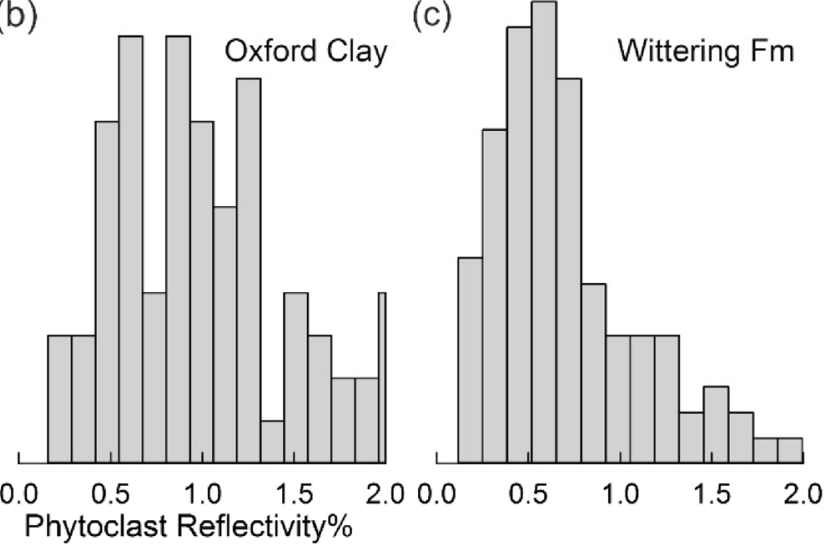


Fig. 5 HOC sorption on Kimmeridge Clay [KC], Oxford Clay $[\mathrm{OxC}]$ and the Wittering Formation [WF]; and their corresponding heavy liquid (HL) and hydrofluoric acid (HF) extracted OM. $C_{\mathrm{s}}=$ concentration of HOC sorbed on the solid, $C_{\mathrm{a}}=$ concentration of $\mathrm{HOC}$ in solution. The OxC data are from Simoes et al. (2011)
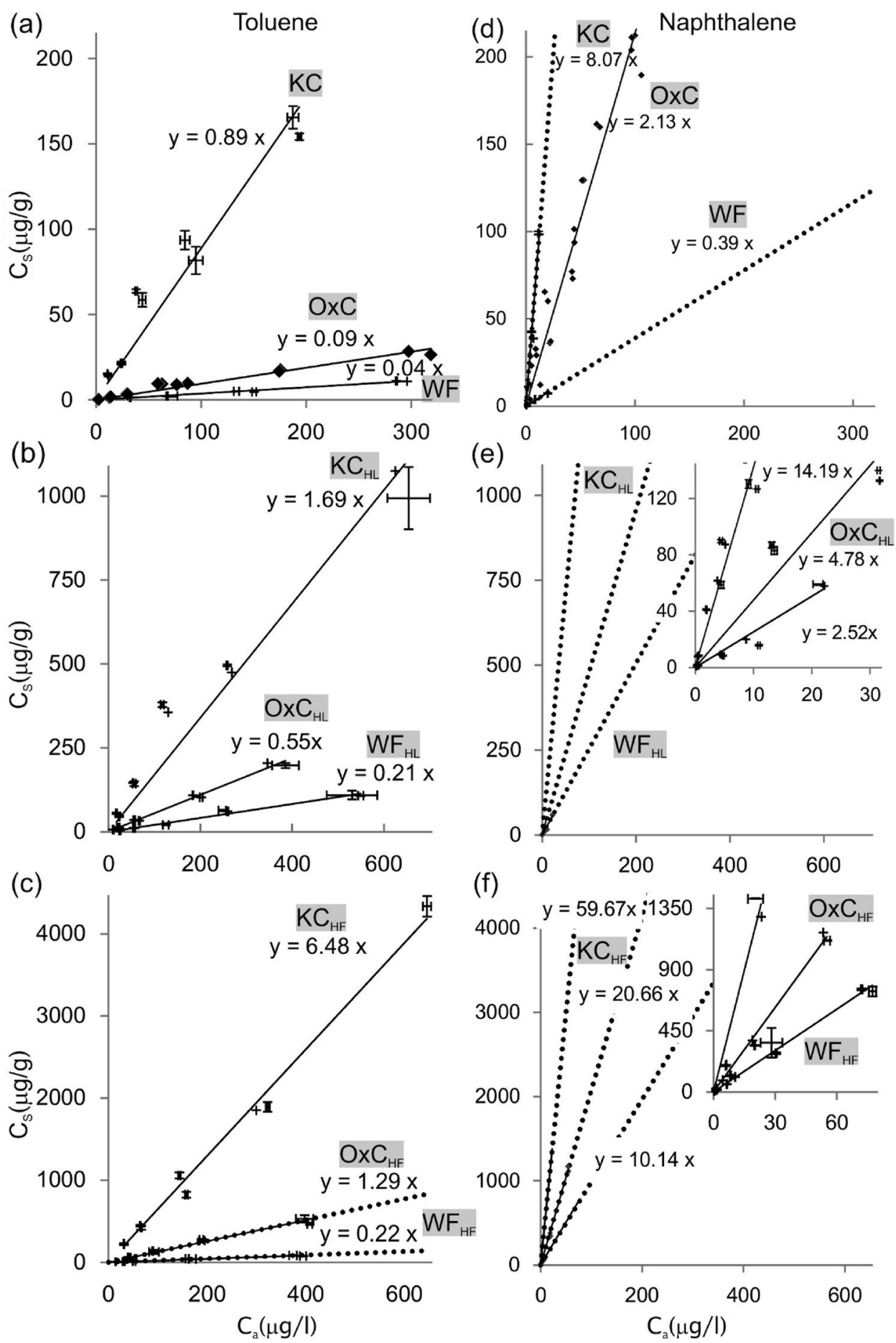

for sorption of toluene on WF where the value was lower. A previous study showed that demineralization of soil altered the functional groups of the humic acids during extraction (Sun et al. 2013). Where $K_{\text {OC }}$ values increased after $\mathrm{HF}$ digestion could be attributed to the silicate coat on the OM surface (Jin and Zimmerman 2010) being dissolved by the HF. The characteristics of the OM may also have been changed by the HF digestion method, potentially the increasing number and size of the contact area resulting in higher capacity to sorb HOCs. 
Table 3 Linear and Freundlich model fits for sorption data for toluene on Kimmeridge Clay $[\mathrm{KC}]$, the Oxford Clay [OxC] and the Wittering Fm [WF] and their corresponding heavy liquid (HL) and hydrofluoric acid (HF) extracted OM

\begin{tabular}{|c|c|c|c|c|c|c|c|c|}
\hline \multirow[t]{3}{*}{ Barrier material } & \multicolumn{8}{|c|}{ Toluene } \\
\hline & \multirow{2}{*}{$\begin{array}{l}S / L \\
g / 1\end{array}$} & \multicolumn{2}{|l|}{ Linear model } & \multicolumn{5}{|c|}{ Freundlich model } \\
\hline & & $K_{\mathrm{d}} \times 10^{3}(\mathrm{l} / \mathrm{g})$ & $R^{2}$ & $\begin{array}{l}K_{\mathrm{F}} \times 10^{3} \\
\left(\mathrm{mg}^{1-\mathrm{n}} \mathrm{l}^{\mathrm{n}} / \mathrm{g}\right)\end{array}$ & $N$ & $R^{2}$ & $\log K_{\mathrm{OC}}(\mathrm{ml} / \mathrm{g})$ & $K_{\mathrm{OC}}(\mathrm{ml} / \mathrm{g})$ \\
\hline \multicolumn{9}{|l|}{ Kimmeridge Clay } \\
\hline $\mathrm{KC}_{\mathrm{HF}}$ & 0.07 & 6481 & 0.99 & 8423 & 0.95 & 0.99 & 3.98 & 9565 \\
\hline $\mathrm{KC}_{\mathrm{HL}}$ & 0.50 & 1695 & 0.94 & 4561 & 0.85 & 0.97 & 3.74 & 5433 \\
\hline $\mathrm{KC}$ & 0.42 & 887 & 0.93 & 1724 & 0.88 & 0.95 & 3.61 & 4069 \\
\hline \multicolumn{9}{|l|}{ Oxford Clay } \\
\hline $\mathrm{OxC}_{\mathrm{HF}}$ & 0.42 & 1286 & 0.97 & 1899 & 0.94 & 0.99 & 3.35 & 2264 \\
\hline $\mathrm{OxC}_{\mathrm{HL}}$ & 4.17 & 548 & 0.99 & 709 & 0.95 & 0.99 & 3.16 & 1438 \\
\hline $\mathrm{OxC}^{\mathrm{a}}$ & 13.22 & 94 & 0.96 & 150 & 0.93 & 0.99 & 3.23 & 1709 \\
\hline \multicolumn{9}{|l|}{ Wittering Fm } \\
\hline $\mathrm{WF}_{\mathrm{HF}}$ & 0.42 & 219 & 0.97 & 380 & 0.91 & 0.99 & 2.62 & 416 \\
\hline $\mathrm{WF}_{\mathrm{HL}}$ & 4.17 & 208 & 0.98 & 131 & 1.08 & 0.99 & 2.84 & 697 \\
\hline WF & 44.17 & 37 & 0.99 & 23 & 1.09 & 0.96 & 2.89 & 771 \\
\hline
\end{tabular}

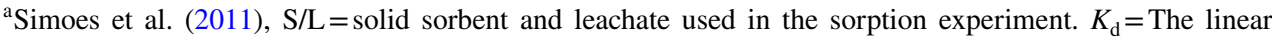
sorption coefficient $(\mathrm{ml} / \mathrm{g}), C_{\mathrm{S}}=K_{\mathrm{d}} C_{\mathrm{a}}, C_{\mathrm{s}}=$ Sorbed contaminant concentration (mass of contaminant $/ \mathrm{mass}$ of solid, $\mathrm{mg} / \mathrm{g}), C_{\mathrm{a}}=$ dissolved contaminant concentration $(\mathrm{mg} / \mathrm{l}), K_{\mathrm{F}}=$ Freundlich isotherm equilibrium coefficient for the sorption reaction $\left(\mathrm{mg}^{1-\mathrm{n}} \mathrm{l}^{\mathrm{n}} / \mathrm{g}\right), n=$ chemical specific constant to take account of heterogeneity, isothermal non-linearity

$C_{\mathrm{S}}=K_{\mathrm{F}} C_{a}^{n} \log K_{\mathrm{OC}}=K_{\mathrm{d}} / F_{\mathrm{OC}}$

Table 4 Linear and Freundlich model fits for sorption data for naphthalene on Kimmeridge Clay [KC], the Oxford Clay [OxC] and the Wittering Fm $[\mathrm{WF}]$ and their corresponding heavy liquid (HL) and hydrofluoric acid (HF) extracted OM

\begin{tabular}{|c|c|c|c|c|c|c|c|c|c|}
\hline \multirow[t]{3}{*}{ Barrier Material } & & \multicolumn{8}{|c|}{ Naphthalene } \\
\hline & & \multirow{2}{*}{$\begin{array}{l}\mathrm{S} / \mathrm{L} \\
\mathrm{g} / \mathrm{l}\end{array}$} & \multicolumn{2}{|l|}{ Linear Model } & \multicolumn{5}{|c|}{ Freundlich Model } \\
\hline & & & $K_{\mathrm{d}} \times 10^{3}(1 / \mathrm{g})$ & $R^{2}$ & $\begin{array}{l}K_{\mathrm{F}} \times 10^{3} \\
\left(\mathrm{mg}^{1-\mathrm{n}} \mathrm{l}^{\mathrm{n}} / \mathrm{g}\right)\end{array}$ & $N$ & $R^{2}$ & $\log K_{\mathrm{OC}}(\mathrm{ml} / \mathrm{g})$ & $K_{\mathrm{OC}}(\mathrm{ml} / \mathrm{g})$ \\
\hline \multirow[t]{3}{*}{ Kimmeridge Clay } & $\mathrm{KC}_{\mathrm{HF}}$ & 0.01 & 59,670 & 0.96 & 25,480 & 1.23 & 0.99 & 4.94 & 88,061 \\
\hline & $\mathrm{KC}_{\mathrm{HL}}$ & 0.25 & 14,198 & 0.92 & 14,664 & 1.09 & 0.96 & 4.66 & 45,506 \\
\hline & $\mathrm{KC}$ & 0.50 & 8073 & 0.98 & 7161 & 1.03 & 0.97 & 4.57 & 37,032 \\
\hline \multirow[t]{3}{*}{ Oxford Clay } & $\mathrm{OxC}_{\mathrm{HF}}$ & 0.03 & 20,661 & 0.99 & 15,986 & 1.04 & 0.96 & 4.59 & 39,212 \\
\hline & $\mathrm{OxC}_{\mathrm{HL}}$ & 0.17 & 4653 & 0.95 & 5391 & 1.01 & 0.97 & 4.09 & 12,213 \\
\hline & $\mathrm{OxC}^{\mathrm{a}}$ & 4.07 & 2137 & 0.95 & 3142 & 0.91 & 0.89 & 4.59 & 38,855 \\
\hline \multirow[t]{3}{*}{ Wittering Fm } & $\mathrm{WF}_{\mathrm{HF}}$ & 0.05 & 10,134 & 0.99 & 10,663 & 1.01 & 0.99 & 4.25 & 17,838 \\
\hline & $\mathrm{WF}_{\mathrm{HL}}$ & 0.50 & 2525 & 0.96 & 2672 & 0.91 & 0.98 & 3.93 & 8459 \\
\hline & WF & 4.17 & 388 & 0.96 & 386 & 1.09 & 0.94 & 3.91 & 8083 \\
\hline
\end{tabular}

\section{Influence of organic matter characteristics on sorption capacity}

The $\mathrm{K}_{\mathrm{OC}}$ of sorption of naphthalene and toluene decreased with increasing effective polarity (Table 5) which corresponds to trends seen in earlier work (Chen et al. 2005; Guo et al. 2013; Kang and Xing 2005; Wang et al. 2007). It has been suggested that polar functional groups provide areas for water clusters to form through hydrogen bonding, thus causing a steric hindrance to the sorption of HOC molecules in the matrix. (Wang et al. 2007). The correlation coefficient of $\log K_{\mathrm{OC}}$ plot with PI (Table 5) using $\mathrm{OM}_{\mathrm{HF}}$ has demonstrated a higher correlation than $\mathrm{OM}_{\mathrm{HL}}$ implying that the $\mathrm{HF}$ extraction method was more efficient than the HL method leading to higher purity $\mathrm{OM}$.

Cornelissen et al. (2005) observed that a high $\mathrm{H} / \mathrm{O}$ ratio correlates to OM which contains comparatively few oxygenbearing functional groups, decreased polarity and increased hydrophobicity and high sorption capacity for non-polar 
Fig. $6 \log K_{\mathrm{OC}}(\mathrm{mg} / \mathrm{l})$ vs TOC $\%$ of sorption data for toluene and naphthalene on the Kimmeridge Clay [KC], the Oxford Clay $[\mathrm{OxC}]$ and the Wittering Fm [WF] and their corresponding heavy liquid (HL) and hydrofluoric acid (HF) extracted $\mathrm{OM}$
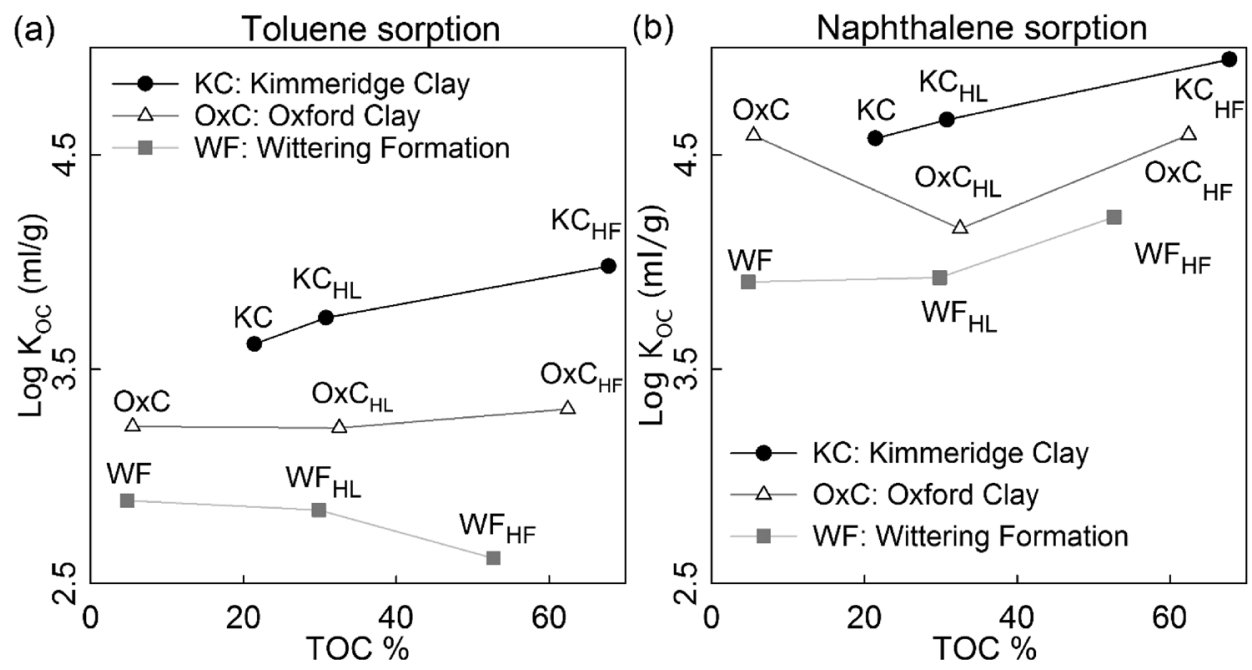

Table 5 Regression equations between $\log K_{\mathrm{OC}}$ and polarity index $(\mathrm{PI}):(\mathrm{O}+\mathrm{N}) / \mathrm{C}$ atomic ratio, $\mathrm{AOM} \%$ and phytoclast $\%$ of extracted $\mathrm{OM}^{*}$

\begin{tabular}{lll}
\hline & Toluene & Naphthalene \\
\hline $\mathrm{OM}_{\mathrm{HF}}$ & $\log K_{\mathrm{OC}}=-3.38 \mathrm{PI}+4.24$ & $\log K_{\mathrm{OC}}=-1.69 \mathrm{PI}+5.06$ \\
& $R^{2}=0.93$ & $R^{2}=0.90$ \\
$\mathrm{OM}_{\mathrm{HL}}$ & $\log K_{\mathrm{OC}}=-1.27 \mathrm{PI}+3.77$ & $\log K_{\mathrm{OC}}=-0.96 \mathrm{PI}+4.62$ \\
& $R^{2}=0.70$ & $R^{2}=0.56$ \\
$\mathrm{OM}_{\mathrm{HF}}$ & $\log K_{\mathrm{OC}}=1.99 \mathrm{Log}(\mathrm{H} / \mathrm{O})+1.70$ & $\log K_{\mathrm{OC}}=1.07 \mathrm{Log}(\mathrm{H} / \mathrm{O})+3.7191$ \\
& $R^{2}=0.99$ & $R^{2}=0.99$ \\
$\mathrm{OM}_{\mathrm{HL}}$ & $\log K_{\mathrm{OC}}=1.84 \mathrm{Log}(\mathrm{H} / \mathrm{O})+2.03$ & $\log K_{\mathrm{OC}}=1.48 \mathrm{Log}(\mathrm{H} / \mathrm{O})+3.25$ \\
& $R^{2}=0.95$ & $R^{2}=0.88$ \\
$\mathrm{OM}_{\mathrm{HF}}$ & $\log K_{\mathrm{OC}}=0.018 \mathrm{AOM} \%+2.450$ & $\log K_{\mathrm{OC}}=0.008 \mathrm{AOM} \%+4.1647$ \\
$\mathrm{OM}_{\mathrm{HL}}$ & $R^{2}=0.97$ & $R^{2}=0.91$ \\
& $\log K_{\mathrm{OC}}=0.011 \mathrm{AOM} \%+2.706$ & $\log K_{\mathrm{OC}}=0.009 \mathrm{AOM} \%+3.800$ \\
$\mathrm{OM}_{\mathrm{HF}}$ & $R^{2}=0.85$ & $R^{2}=0.73$ \\
& $\log K_{\mathrm{OC}}=-0.021$ phy $\%+3.856$ & $\log K_{\mathrm{OC}}=-0.010 \mathrm{phy} \%+4.86$ \\
$\mathrm{OM}_{\mathrm{HL}}$ & $R^{2}=0.85$ & $R^{2}=0.79$ \\
& $\log K_{\mathrm{OC}}=-0.012$ phy $\%+3.562$ & $\log K_{\mathrm{OC}}=-0.009$ phy $\%+4.463$ \\
\hline
\end{tabular}

* Derived from three sources (Oxford Clay, Kimmeridge Clay and the Wittering Formation that have been treated either by hydrofluoric acid (HF) or heavy- liquid- extraction (HL)) chemicals. Similarly, in this study, $\log \mathrm{H} / \mathrm{O}$ has a strong positive relationship with $\log K_{\mathrm{OC}}$.

Karapanagioti and Sabatini (2000) proposed that the $K_{\mathrm{OC}}$ of a sediment could be predicted from the sum of sorption capacities of different fractions described by their organic matter subgroup (AOM, phytoclasts, and opaque particles). In their study they measured the $K_{\mathrm{OC}}$ of samples at a range of depths in the Canadian River alluvial aquifer material, alluvium and terrace deposits of Quaternary Holocene age. The $K_{\mathrm{OC}}$ values for organic subgroups at shallow depths were successfully used to predict $K_{\mathrm{OC}}$ values for composite samples from greater depths. Whereas, Karapanagioti and Sabatini (2000) used samples within same layer but from different depths, in this study, sediments with different geological histories were isolated. The isolated $\mathrm{KC}$ was predominately AOM (84\%) and the isolated WF was predominantly phytoclasts. The $K_{\mathrm{OC}}$ of these isolates was used in the summative model of Karapanagioti and Sabatini (2000) to predict $K_{\mathrm{OC}}$ values for OxC. The result considerably over estimated the observed $K_{\mathrm{OC}}$ of toluene and naphthalene sorption on this sediment.

Only three different sediments were tested, two of which are the main geological formations used for landfill sites in the southern UK. There appeared to be a positive correlation between the $K_{\mathrm{OC}}$ values for these contaminants and the proportion of AOM in the sediment (Table 5), whereas there is a negative correlation with the percentage of phytoclasts. Further tests on a range of sediments with different AOM and phytoclast concentrations would result in greater confidence in the relationship between $K_{\mathrm{OC}}$ and these sediment components. However, the application of the model suggests that other factors are influencing HOC sorption. AOM is 
morphologically without any obvious internal or external structure that gives a clue as to its origin or properties. It is found within high productivity/preservation environments where organic matter from the otherwise non-resistant cellular material has been preserved under anaerobic or euxinic conditions in a stratified water column than can be a marine or lacustrine environment. Typical high TOC bearing sediment is a distinctive black or brown laminated sediment with a high framboidal pyrite content. The high preserved organic matter often caused by the stratified euxinic water column rises into the photic zone where microbial production thrives, and the euxinic water could rapidly cause mass mortality and preserved the bacterial remains from decomposed. Following deposition AOM forms a non-particulate network within the sediments often making up a significant component of the rock by volume. During burial this AOM can then significantly alter during diagenesis. This suggests, therefore, that sorption of HOCs by sediments of different diagenetic histories cannot be predicted solely on the basis of petrological methods.

\section{Conclusion}

In this study, the sorption capacity measured by the linear sorption coefficients $\left(K_{\mathrm{d}}\right)$ for toluene and naphthalene on $\mathrm{KC}$ were significantly higher than other natural sorbents in the literature. The study used only a low concentration range, reflecting the low concentrations of toluene and naphthalene found in landfill leachate in the UK. Further studies, at higher concentrations would enable direct comparison with literature studies. It is possible that non-linear sorption may be observed in these sediments over a higher concentration range, as has been found in other studies. When $K_{\mathrm{OC}}$ values for the different sediments were compared it was found that the $\mathrm{AOM}$ content in the $\mathrm{KC}$ and $\mathrm{OxC}$ strongly influenced sorption capacity, whereas the limited amount of AOM in the WF combined with a greater proportion of phytoclasts showed less sorption capacity. While polarity, $\mathrm{H} / \mathrm{C}$ and $\log$ $\mathrm{H} / \mathrm{O}$ were also factors affecting HOC sorption, this study demonstrated that the proportion of AOM was also a major influence. However, the proportion of AOM determined by petrological methods could not be used to predict sorption capacities in sediments from different sources. AOM extracted from the $\mathrm{KC}$ appeared to have a higher sorption capacity than $\mathrm{AOM}$ from the $\mathrm{OxC}$ indicating that diagenesis also plays a part. While AOM is considered as the major controlling factor, the degree of diagenesis may also influence on AOM sorption capacity.

In this study, AOM found in $\mathrm{KC}$ and $\mathrm{OxC}$ resulted in high sorption of toluene and naphthalene. When these materials are used as landfill barriers, there will be a greater retardation of leachate pollutants than might be expected from the OM content of these sediments. This demonstrates the importance of using site-specific data in risk assessments rather than relying on literature values. Petrological determinations of OM were shown to be an indicator of the mechanisms and potential magnitudes of sorption processes for HOCs. However, further work is needed to confirm the relationship between AOM, degree of diagenesis, and sorption of a range of HOCs of differing hydrophobicity to enable landfill operators to base their risk assessments on petrological examination of sediments.

Supplementary Information The online version contains supplementary material available at https://doi.org/10.1007/s12665-021-09632-4.

Acknowledgements The authors gratefully acknowledge the assistance of technical staff from National Oceanography Centre and the Environmental Laboratory, University of Southampton, UK. This research was funded by EPSRC EP/G016305/1. The manuscript submission is supported by a Grant from MOST104-2628-M-001-007-MY3 and MOST107-2116-M001-004. Thanks go to Dr. Lou-Chuang Lee and Dr. Kuo-Fang Huang from Institute of Earth Sciences, Academia Sinica, Taiwan, for kindly guide and encouragement on publishing this paper.

Author contributions Conceptualization: AS, DS, JM; Methodology: AS, JM; Formal analysis and investigation: P-RH; Writing-original draft preparation: P-RH; Writing-review and editing: AS, DS, JM; Funding acquisition: AS, DS, JM; P-RH; Resources: AS, DS, JM; Supervision: AS, DS, JM; Field sampling: JM, P-RH, AS, DS.

Open Access This article is licensed under a Creative Commons Attribution 4.0 International License, which permits use, sharing, adaptation, distribution and reproduction in any medium or format, as long as you give appropriate credit to the original author(s) and the source, provide a link to the Creative Commons licence, and indicate if changes were made. The images or other third party material in this article are included in the article's Creative Commons licence, unless indicated otherwise in a credit line to the material. If material is not included in the article's Creative Commons licence and your intended use is not permitted by statutory regulation or exceeds the permitted use, you will need to obtain permission directly from the copyright holder. To view a copy of this licence, visit http://creativecommons.org/licenses/by/4.0/.

\section{References}

Chen B, Johnson EJ, Chefetz B, Zhu L, Xing B (2005) Sorption of polar and nonpolar aromatic organic contaminants by plant cuticular materials: role of polarity and accessibility. Environ Sci Technol 39:6138-6146. https://doi.org/10.1021/es050622q

Chi FH (2014) The influence of black carbon on the sorption and desorption of two model PAHs in natural soils. Bull Environ Contam Toxicol 92:44-49. https://doi.org/10.1007/s00128-013-1127-z

Chiou CT, Kile DE, Rutherford DW, Sheng GY, Boyd SA (2000) Sorption of selected organic compounds from water to a peat soil and its humic-acid and humin fractions: Potential sources of the sorption nonlinearity. Environ Sci Technol 34:1254-1258. https://doi. org/10.1021/es990261c 
Cornelissen G, Gustafsson Ö, Bucheli TD, Jonker MTO, Koelmans AA, van Noort PCM (2005) Extensive sorption of organic compounds to black carbon, coal, and kerogen in sediments and soils: mechanisms and consequences for distribution, bioaccumulation, and biodegradation. Environ Sci Technol 39:6881-6895. https:// doi.org/10.1021/es050191b

Delle Site A (2001) Factors affecting sorption of organic compounds in natural sorbent/water systems and sorption coefficients for selected pollutants. A review. J Phys Chem Reference Data 30:187-439

Ebukanson EJ, Kinghorn RRF (1985) Kerogen facies in the major Jurassic Mudrock formations of southern England and the implication on the depositional-environments of their Precursors. J Petrol Geol 8:435-462. https://doi.org/10.1111/j.1747-5457. 1985.tb00283.x

Environment Agency (2001) Pollution inventory discharges to sewer or surface water from landfill leachate. Environment Agency, Bristol

Environment Agency (2003) Updating the landfil leachate pollution inventory reporting tool. Environment Agency, Bristol

Environment Agency (2009) Attenuation of organic contaminants in leachate by mineral landfill liners. Environment Agency, Rio House, Waterside Drive, Aztec West, Almondsbury, Bristol, BS32 4UD

Fishman NS, Hackley PC, Lowers HA, Hill RJ, Egenhoff SO, Eberl DD, Blum AE (2012) The nature of porosity in organic-rich mudstones of the Upper Jurassic Kimmeridge Clay Formation, North Sea, offshore United Kingdom. Int J Coal Geol 103:32-50. https:// doi.org/10.1016/j.coal.2012.07.012

Guo X, Wang X, Zhou X, Ding X, Fu B, Tao S, Xing B (2013) Impact of the simulated diagenesis on sorption of naphthalene and 1-naphthol by soil organic matter and its precursors. Environ Sci Technol 47:12148-12155. https://doi.org/10.1021/es401732e

Han LF, Sun K, Jin J, Xing BS (2016) Some concepts of soil organic carbon characteristics and mineral interaction from a review of literature. Soil Biol Biochem 94:107-121. https://doi.org/10.1016/j. soilbio.2015.11.023

Han LF, Wang ZY, Keiluweit M, Yang Y, Sun K, Zhang ZY, Xing BS (2018) Effect of simulated diagenesis on the compositions, chemical stability and sorption properties of natural and engineered organic matter with different mineral contents. Org Geochem 120:1-11. https://doi.org/10.1016/j.orggeochem.2018.02.009

Harris D, Horwath WR, van Kessel C (2001) Acid fumigation of soils to remove carbonates prior to total organic carbon or carbon-13 isotopic analysis. Soil Sci Soc Am J 65:1853-1856. https://doi. org/10.2136/sssaj2001.1853

Headley JV, Boldt-Leppin BEJ, Haug MD, Peng JM (2001) Determination of diffusion and adsorption coefficients for volatile organics in an organophilic clay-sand-bentonite liner. Can Geotech J 38:809-817. https://doi.org/10.1139/cgj-38-4-809

Huang W, Peng Pa YuZ, Fu J (2003) Effects of organic matter heterogeneity on sorption and desorption of organic contaminants by soils and sediments. Appl Geochem 18:955-972. https://doi.org/ 10.1016/S0883-2927(02)00205-6

Huang HC, Lee JF, Lee CK, Chen JC (2006) The structural and sorptive characteristics of high-surface-area carbonaceous material (HSACM) in soils. J Hazard Mater 138:485-492. https://doi.org/ 10.1016/j.jhazmat.2006.05.094

Huggett JM, Gale AS, Wray DS (2005) Diagenetic clinoptilolite and opal-CT from the middle Eocene Wittering Formation, Isle of Wight, UK. J Sediment Res 75:585-595. https://doi.org/10.2110/ jsr.2005.048

Jin J, Zimmerman AR (2010) Abiotic interactions of natural dissolved organic matter and carbonate aquifer rock. Appl Geochem 25:472-484. https://doi.org/10.1016/j.apgeochem.2009.12.012
Kang S, Xing B (2005) Phenanthrene sorption to sequentially extracted soil humic acids and humins. Environ Sci Technol 39:134-140. https://doi.org/10.1021/es0490828

Karapanagioti HK, Sabatini DA (2000) Impacts of heterogeneous organic matter on phenanthrene sorption: different aquifer depths. Environ Sci Technol 34:2453-2460. https://doi.org/10.1021/es990 938w

Kennedy MJ, Pevear DR, Hill RJ (2002) Mineral surface control of organic carbon in black shale. Science 295:657. https://doi.org/ $10.1126 /$ science. 1066611

Lichtfouse E, Schwarzbauer J, Robert DD (2005) Environmental chemistry: green chemistry and pollutants in ecosystems. Springer, Berlin, London

Ligouis B, Kleineidam S, Karapanagioti HK, Kiem R, Grathwohl P, Niemz C (2005) Organic petrology: a new tool to study contaminants in soils and sediments. In: Lichtfouse E, Schwarzbauer J, Robert D (eds) Environmental Chemistry. Springer, Berlin Heidelberg, pp 89-98. https://doi.org/10.1007/3-540-26531-7_9

Mackay AA, Gschwend PM (2000) Sorption of monoaromatic hydrocarbons to wood. Environ Sci Technol 34:839-845. https://doi. org/10.1021/es9900858

Morgans-Bell HS et al (2001) Integrated stratigraphy of the Kimmeridge Clay Formation (Upper Jurassic) based on exposures and boreholes in south Dorset, UK. Geol Mag 138:511-539. https:// doi.org/10.1017/S0016756801005738

Okiongbo KS, Aplin AC, Larter SR (2005) Changes in type II kerogen density as a function of maturity: evidence from the Kimmeridge Clay Formation Energ. Fuel 19:2495-2499. https://doi.org/10. 1021/ef050194+

Perez MAP, Moreira-Turcq P, Gallard H, Allard T, Benedetti MF (2011) Dissolved organic matter dynamic in the Amazon basin: sorption by mineral surfaces. Chem Geol 286:158-168. https:// doi.org/10.1016/j.chemgeo.2011.05.004

Pilawa B, Więckowski AB, Pietrzak R, Wachowska H (2002) Oxidation of demineralized coal and coal free of pyrite examined by EPR spectroscopy. Fuel 81:1925-1931. https://doi.org/10.1016/ S0016-2361(02)00131-X

Riding JB, Kyffin-Hughes JE (2009) The use of pre-treatments in palynological processing. Rev Palaeobot Palyno 158:281-290. https://doi.org/10.1016/j.revpalbo.2009.09.009

Simoes A, Stringfellow AM, Smallman D, Beaven R, Marshall J, Powrie W, Potter HAB (2011) Sorption of organic contaminants by Oxford Clay and Mercia Mudstone landfill liners. Q J Eng GeolHydrogeol 44:345-360. https://doi.org/10.1144/1470-9236/ 09-003

Sun K, Jin J, Kang M, Zhang Z, Pan Z, Wang Z, Wu F, Xing B (2013) Isolation and characterization of different organic matter fractions from a same soil source and their phenanthrene sorption. Environ Sci Technol 47:5138-5145. https://doi.org/10.1021/es3052087

Trellu C, Mousset E, Pechaud Y, Huguenot D, van Hullebusch ED, Esposito G, Oturan MA (2016) Removal of hydrophobic organic pollutants from soil washing/flushing solutions: a critical review. J Hazard Mater 306:149-174. https://doi.org/10.1016/j.jhazmat. 2015.12.008

Tyson R (2012) Sedimentary organic matter: organic facies and palynofacies. Springer, Netherlands

Wang X, Cook R, Tao S, Xing B (2007) Sorption of organic contaminants by biopolymers: role of polarity, structure and domain spatial arrangement. Chemosphere 66:1476-1484. https://doi.org/ 10.1016/j.chemosphere.2006.09.004

Weber WJ, LeBoeuf EJ, Young TM, Huang W (2001) Contaminant interactions with geosorbent organic matter: insights drawn from polymer sciences. Water Res 35:853-868. https://doi.org/10.1016/ S0043-1354(00)00339-0 
Yamamoto M, Kayanne H, Yamamuro M (2001) Characteristics of organic matter in lagoonal sediments from the Great Barrier Reef. Geochem J 35:385-401. https://doi.org/10.2343/geochemj.35.385

Yule BL, Roberts S, Marshall JEA (2000) The thermal evolution of sporopollenin. Org Geochem 31:859-870. https://doi.org/10.1016/ S0146-6380(00)00058-9

Zhang J, He M (2010) Effect of structural variations on sorption and desorption of phenanthrene by sediment organic matter. J Hazard
Mater 184:432-438. https://doi.org/10.1016/j.jhazmat.2010.08. 123

Publisher's Note Springer Nature remains neutral with regard to jurisdictional claims in published maps and institutional affiliations. 